\title{
POETRY AND THE WORLD OF BUSINESS - AN EXPLORATION
}

GILLIAN PRITCHETT, MA. CPFA. 
Despite a lengthy career in the international department of Lloyds Bank of London, the closest T. S. Eliot ever came to writing about the business world was in these lines from The Waste Land:

At the violent hour, when the eyes and back

Turn upward from the desk, when the human engine waits

Like a taxi throbbing waiting... ${ }^{1}$

And although Dana Goia believed that poetry could help creative thinking he admitted that "American poetry has defined business mainly by excluding it. Business does not exist in the world of poetry, and therefore by implication it has become everything that poetry is not-a world without imagination, enlightenment, or perception. It is the universe from which poetry is trying to escape" (Goia, 1992). But let us not pause to reflect on the extent to which poets write about business - the purpose of this article is to explore the various ways in which poetry can add value in the world of business.

Whilst most people can accept a potential connection between poetry and advertising, they tend to be sceptical that reading poems and experiencing the process of getting to grips with their possible meaning can be of help in business. The idea that poetry can help with strategic thinking, in decision-making, in communications, in the way we look at situations, the way we think, the way we interact with others, the way we express our opinions, with creativity and innovation leaves many people struggling. And yet - reputable companies, world-class CEOs, institutions, and scholars propound the value of poetry for business.

Concerned that business and management strategy were too often reduced to a narrow, toolbox approach, the Strategy Institute of the Boston Consulting Group commissioned Clare Morgan to work with them on a project exploring the relationship between poetry and strategic thinking. The investigation of the role poetry might play in business by Morgan and her colleagues is recorded in the book, What Poetry brings to business ${ }^{2}$ published in 2010. Ted Buswick, who initiated the project, said, "What our theories offer isn't an 'alternative' approach. It's a tough, skills-based initiative aimed at adding to the repertoire of analysis-based thinking spaces."

The BCG Strategy Institute was not alone in recognising the value of poetry in business. Its value has been recognised by many a CEO. In 2007 Sidney Harman, founder of Harman Industries said, "I used to tell my senior staff to get me poets as managers, [...] Poets are our original systems thinkers. They look at our most complex environments and they reduce the complexity to something they begin to understand" (Rubin, 2007). When asked about his success in turning Jell-O from a business with a seven million dollar loss to a twenty million dollar success Dana Goia, a poet and author of Can Poetry Matter? replied, "I looked at things differently. I made associative connections. I thought around and beyond and through the data that confronted me" (Morgan, 2010, p. 43). He ascribed this to the fact that he was also a poet.

Business schools use poetry to teach business studies for example Babson College requires its MBA candidates to take a five-week creativity workshop early on in the programme. Students are randomly assigned to one of seven art seminars which include poetry. Professor Mary Pinard says "There is a lot of ambiguity in the creative process, and that's hard for people who want answers. [... ] Yet successful entrepreneurs are people who can stay open to possibilities, take risks, and find new solutions to problems [... ] The nature of what entrepreneurs do is very close to what poets do." Tom Chandler, poet laureate of Rhode Island and a full-time professor at Bryant College in Smithfield teaching literature classes and a poetry workshop for undergraduates says,

Published in 1922 in the UK in the October issue of The Criterion and in the US in the November issue of The Dial. It was published in book form in the US by Boni and Liveright in December 1922 and in the UK by Hogarth Press in September 1923. 
"Business school promotes a very conformist culture [... ] but I want students to take that coat off while they are in my class. Individuality is contagious just as conformity is contagious. I see these two at war." For Chandler the value of poetry is not limited to just making students more creative thinkers, it also makes them more wellrounded people. It could be argued that this is important in increasingly global and often uncertain economy.

Lieutenant General James Lennox, Superintendent of the United States Military Academy at West Point from 2001 to 2006, believed that poetry was of value in achieving good communications: "Those who can't communicate can't lead. Poetry, because it describes reality with force and concision, provides an essential tool for effective communication. [... In studying poetry, cadets gain a unique appreciation for the power of language" (Lennox, 2006). To this day, poetry is part of the curriculum. Indeed, the 2016 curriculum not only includes poetry in courses on British Literature, American Literature, and World Literature, but a 36-hour course just on poetry: "Embracing a wide variety of authors, works, periods, traditions, and forms, this course considers the literary genre through which human beings have expressed their most intensely imaginative visions of themselves and the world, and connections between the two. Some consideration of poetics and prosody will complement the cadets' reading of verse that ranges from Japanese haiku through the Shakespearean sonnet to the free-verse creations of modern and contemporary poets." As well as developing communication skills, Lennox (2006) also considered that "poetry confronts cadets with new ideas that challenge their worldview. [... ] In teaching cadets poetry, we teach them not what to think, but how to think. [...] We may not produce a poet laureate at the United States Military Academy. If, however, we develop graduates who can communicate clearly, think critically, and appreciate the world through different perspectives, we will provide the Army and the nation with better leaders."

Clare Morgan (2010, p. 14) suggests that poetry can help business in the following ways:

- A poem is multidimensional which develops our ability to detect different modes of meaning and to deal with ambiguity and uncertainty.

- A poem doesn't offer closure - this teaches us to handle non-resolution

- A poem isn't based in a logical deductive mode and so we learn to make associative connections

- Poems can show the ordinary as extraordinary which encourages us to question givens and makes us more aware of complexity

- A poem is almost infinitely interpretable and can help us to consider the views of others, to recognise that 'meaning' is unstable and to examine and revise our current insights and perceptions

- A poem operates at different levels of accessibility which could enable us to detect weak as well as strong signals and to seek less obvious linkages

- A poem is full of coexistent complements and contradictions which could develop our ability to time judgements carefully and be aware that binary thinking is not enough

- By drawing attention to human needs and motivations poetry could help us to make decisions in a more comprehensive context and address ethical issues

- By exploring emotional complexity poems could help us develop the ability to offer wholeness of response

Let us take a top level look at the potential value that poetry can bring to some specific business contexts. 


\section{POETRY AND MARKETING}

Poetry and advertising are no strangers. Klepper and Piller (2004) contend that "socially, advertising has long taken over the community-building function of the bard, gluing together individuals with the semiotics of shared symbols and narratives". Referring to the advertising slogans, "Have a Break, Have a Kitkat" and "Wonderbra for the way you are", Clare Morgan (2010, p. 31) suggests, "the power of poetry has been added to the words of the advertisements to reach beyond those words and elicit a response that does not depend on logic or fact. The poetry aspect has reached into the customer's decision-making process to assess nonlogical but highly decisive responses that affect the purchasing patterns of whole sectors of society."

Poems have often been used to market products and this was especially evident at the start of the new millennium. In March 2000, The New York Times ran an article on the use of poetry by marketing departments reporting that "American Airlines is the latest company to jump on the poetry bandwagon. In April, National Poetry Month, flight attendants on selected international flights will hand out 100,000 copies of a poetry anthology along with the peanuts" (Meredith, 2000). Volkswagen put 40,000 copies of poetry books in the glove boxes of its new cars. Lancome paid for 15,000 copies of an anthology called "Great Love Poems" given out on Valentine's Day (Meredith, 2000). In 2000, Monster.com announced recordbreaking traffic spikes following the launch of its new advertising campaign during the broadcast of Super Bowl XXXIV. In the commercial, a young woman standing at an urban crossroads is 'advised' by a cast of characters as they walk past her. The advice is recited in the form of lines from Robert Frost's poem, The Road Not Taken. The final lines, delivered by an elementary school teacher and some of her students, suggest that the choices you take will make all the difference in your career.

Two roads diverged in a wood, and I,

I took the one less traveled by,

And that has made all the difference.

In the abstract to his article, What Business can learn from the Poetry of Thomas Kinsella, John Fanning (2007, p. 46) wrote, "A growing number of voices, [... ], call for a greater embrace of literature and the arts in seeking to understand and master the world of marketing and business. The contention is that creative writers, such as novelists and poets, can articulate usefully the consumer condition. In this spirit, a close reading of the poetry of Thomas Kinsella, [... ], can shed insight into a number of aspects of marketing and management practice. These aspects include the role of creative and innovative processes in business; the frequent misuse of scientific approaches; a tendency to settle for the second rate - 'the ease of the spurious'; the need for thoroughness in new product development - 'reading the ground'; and the consequences of corporate, and brand, amnesia."

Since marketing is only as good as the research that underpins it, could poetry have a role to play in consumer research? John F. Sherry, Jr. and John W. Schouten considered that poetry could be included in the various methods for data collection since it might serve to tap into consumers inner worlds, cogently arguing the case in A Role for Poetry in Consumer Research (Sherry and Shouten, 2002). They contend, "if, $[\ldots .$.$] we accept that the task of science is to accommodate disparate voices and attend to the polyphony$ of science (Jackson 1998), then poetry is a viable vessel for the conveyance of research experiences." They go on to argue, "perhaps former poet laureate Rita Dove's belief that poetry makes 'the interior life of one individual available to others' (Dove, 1994, p. 25) can serve as a rationale for the rapprochement of art and science in consumer research." They considered that poetry could be included in the various methods for data collection since it might serve to tap into consumers inner worlds. Either the consumer 
would express their views and feelings in poetry or they could share their feelings with a researcher who would express them in poetic form. They conclude that "we have discussed two ways that poetry can inform studies of consumer behavior: as reflexivity within research and a revelation of researcher point of view and as stand-alone qualitative research in its own right. Yet these are not the only means by which poetry may contribute to the discourse on consumer behavior. We have written this article simply to launch the tide of exploration" (Sherry and Shouten, 2002, p. 230).

\section{POETRY AND BUSINESS STRATEGY}

Clare Morgan (2005) used the poem "Traveling through the dark" by William Stafford at a workshop she conducted with a high tech company in the UK. The CEO wanted to spend time at a strategy retreat developing the thinking of his management team as well as addressing the concrete issues that faced the company; "being a poetry reader himself-he was eager to see how exposure to some poetry would affect the way his team approached certain key issues."

When asked what approach she took in presenting such an unusual subject, Clare Morgan (2010) explained that she chose a poem that "showed how complex making decisions is: complex, that is, in terms of how so many different elements can affect how we see 'the facts."'14 For Morgan, Traveling through the Dark was appropriate because "the content of the poem opened up a wide-ranging discussion of real issues like: when is the right time to kill off a project? What influences we may not be aware of are affecting how we prioritize value and make fine judgements? The poem also opened up how we may be judged, for making tough choices that affect the lives of others. [... ] The CEO liked the way the discussion highlighted that in many cases there is not a clear cut right or wrong to the decision we're faced with. Sometimes the information we have is incomplete, or the different strands of need cannot be definitively prioritized."

By learning - or re-discovering - how to think laterally and how to recognise and accept ambiguity business leaders and managers might be better equipped to take oftimes complex decisions.

\section{POETRY AND DECISION-MAKING}

Can reading poetry make you think differently? Intuitively, one would answer yes, but is there empirical evidence to support this intuition? And will the process of understanding poems open spaces in your mind that will facilitate strategic planning, creativity, communications? Wolfgang Iser in his essay, The Reading Process: A Phenomenological Approach, proposes that reading literary texts fosters an ability to ask questions and make connections. In the world of business "we look forward, we look back, we decide, we change our decisions, we form expectations, we are shocked by their non-fulfilment, we question, we use, we accept, we reject" (Iser, 1974). This is exactly what we do when we read a poem and try to grasp its meaning. Because of this, Iser believes that literature gives us the chance to formulate the unformulated. Morgan (2010, p. 12) considers that "reading poetry requires - demands - a very particular way of thinking. And that way of thinking is vitally important in addressing the complexities of the economic, social, and political world we live in." Ted Buswick (2005) suggests "reading poetry opens up new thinking spaces, and accessing those spaces requires you to develop a new set of thinking skills."

\footnotetext{
3 "Poetry in the Boardroom: Thinking Beyond the Facts: A Roundtable Discussion among Clare Morgan, Kirsten Lange, Ted Buswick, and Nancy Healy," Journal of Business Strategy 26 (January-February 2005), pp. 34-40.

4, 5 Ibid.
} 
Clare Morgan (2010) argues that a poem is:

a distillation of thought, experience, emotion into a tightly controlled form which utilizes words, images, sound and rhythm patterns to create a complex set of meanings that constantly form and re-form themselves. Its components take it beyond argument into a realm where expectations of single, analysable meaning are deliberately questioned and subverted. All art does this, but poems do it in a particularly condensed and therefore intensive way. A poem is a puzzle with multiple, inexhaustible, co-existent and interchangeable - 'solutions', each more or less dependent on the others for validity. This means that the desire for closure, which drives most business considerations, the desire for pursuing the shortest route between $A$ and $B$, another dominant mode in business thinking - won't get you anywhere at all when you're faced with a poem.

For Morgan, a poem is not an act of logical deduction; "if you try to cut to the chase the poem will elude you" (Morgan, 2010, p. 23). In other words, a poem needs to be read carefully and thought about rather than being read rapidly and then a hurried decision made about its meaning. This is in stark contrast with the business world where typically facts are gathered, analysed and a decision made, usually with tight deadlines that preclude a careful thinking through of the issues, the possible decisions and the potential outcomes of those decisions.

In What Poetry Brings to Business, Morgan discusses the notion of sharpeners and levellers. The Leveller likes to categorise, levels differences and emphasises similarities and finds the unique, unclassified sensation difficult. In contrast the Sharpener tolerates anomalies; is ready to think and perform symbolically, may seek out ambiguity and variability of classification; plans ideationally and is ready to assume an attitude toward 'the merely possible' (Morgan, 2010, pp. 36-37).

\section{Morgan argues that engaging with poetry fosters a different mindset from that which typical analytical business training promotes. In today's complex world, the sharpener mindset is essential for strategic thinking and for being creative and innovative. Leaders need to be sharpeners.}

Reuven $\operatorname{Tsur}^{6}$ undertook experiments to see whether how a person is trained to think makes a difference as to whether they use sharpener or leveller strategies and whether having been trained to work with poems enables someone to use different thinking strategies than if they were not. Tsur worked with groups of literary professionals and students as well as control groups of people who were not literary trained. Participants had to evaluate different versions of a poetry text considering criteria such as static-dynamic, open-closed, emotional-unemotional. The differences perceived by the literary trained group were markedly greater. Tsur's results indicated that the non-literary trained participants tended to level out the differences and lacked the skills associated with those who had benefited from literary training.

\footnotetext{
${ }^{6}$ Reuven Tsur is professor emeritus of Hebrew literature and literary theory at Tel Aviv University. He is known for his theory of Cognitive Poetics.

${ }^{7}$ From The Hawk in the Rain (1957).
} 
Companies need to be innovative in order to differentiate. Can poetry help with creativity and innovation? This question was raised in 1999 by Jules Mann of the Poetry Society: "regarding the world of business and poetry, I spoke recently with Elizabeth Wild of ARCO [... ] she referred to a book by business guru Charles Handy titled 'The New Alchemists', which indicates that leading business are thinking more about motivation, and ways of encouraging creativity and not stifling it. Handy notes a trend towards many more workshops and courses on how to stimulate creativity... perhaps poetry could be worked in there somehow" (Mann, 1999)?

One of the most ambitious attempts to define the nature of creativity was Arthur Koestler's The Act of Creation: "The creative act is not an act of creation in the sense of the Old Testament. It does not create something out of nothing; it uncovers, selects, reshuffles, combines, synthesises already existing facts, ideas, faculties, skills." This led Koestler to his creative theory of 'bisociation' in order to distinguish between routine thinking on a single plane and creative thinking that always occurs on more than one plane. "The bisociative act connects previously unconnected matrices of experience - the essence of discovery is that unlikely marriage of cabbages and kings, of previously unrelated frames of reference or universes of discourse whose union will solve previously unsolvable problems" (Fanning, 2007, p. 48).

During the past decade businesses have been harangued from all sides on the need to become more innovative and creative if they are to have any hope of surviving in an increasingly competitive world. From Michael Porter: 'innovation is the central issue in economic prosperity', to Gary Hamel: 'radical non-linear innovation is the only way to escape the ruthless hypercompetition that has been hammering down margins in industry after industry', all of the 'big beasts' of the business academic world have been singing the same tune. In the past business has never been shy of ransacking other disciplines for any insights they may have to offer, so it should come as no surprise that the humanities have now become a particular target (Fanning, 2007, p. 46).

It should follow therefore that when trying to arrive at creative solutions the more we know about the background to the problem under review the more likely we are to make the necessary connections and, as the poet Kinsella advises, we need to keep stirring the pot (Fanning, 2007, p. 48):
We have to dig down
sieve, scour and roughen
make it all fertile and vigorous
get the fresh rain down.

The genesis for Fanning's article was a request from Diageo's head of advertising to address a conference of their marketing staff and agency teams on the subject of creativity in November 2006. Thomas Kinsella's connections with Guinness - he was brought up in the area, has written extensively about it and both his father and grandfather worked for the brewery.

A useful poem to study in the context of creativity is The Thought Fox ${ }^{7}$ by Ted Hughes which describes how the moment of creative insight creeps up on the poet.

I imagine this midnight moment's forest:

Something else is alive

Beside the clock's loneliness

And this blank page where my fingers move. 
The opening line, "I imagine this midnight moment's forest", warns us that this is not a poem about a forest or a fox. The poet is sitting alone at the midnight hour, faced with a blank page. The process of creativity is like a fox creeping through the forest making footprints in the snow. The snow represents the white page. The footprints are the words that slowly appear:

Cold, delicately as the dark snow

A fox's nose touches twig, leaf;

Two eyes serve a movement, that now

And again now, and now, and now

Sets neat prints into the snow

Between trees, and warily a lame

Shadow lags by stump and in hollow

Of a body that is bold to come

At the end of the poem the page is printed. A poem has been produced.

Till, with a sudden sharp hot stink of fox,

It enters the dark hole of the head.

The window is starless still; the clock ticks,

The page is printed.

This is reminiscent of the recommendation Ted Hughes gives in Poetry in the Making: "Imagine what you are writing about. See it and live it. Do not think it up laboriously, as if you were working out mental arithmetic. Just look at it, touch it, smell it, listen to it, turn yourself into it. When you do this, the words look after themselves, like magic" (Hughes, 1967, pp. 17-19).

\section{Luc de Brabandere ${ }^{8}$, a BCG fellow and author of The Forgotten Half of Change, argues that creativity is central to change in an organisation but suggests that central to creativity is the ability to shift perceptions since such changes can make way for imaginative leaps that generate new ideas that fuel organisational changes.}

He uses poetry to exemplify some of the challenges of creativity. One of his clients was a global hotel chain who put their request for proposals in the form of a poem in order to find consultants who would bring breadth and freshness to the project. de Brabendere (2005) says "a strategic vision is a representation - an ambitious image of a future state that is radically preferable to the current state." Studying relevant poems could assist in this process. He talks of the need to have an attitude of non finito whereby even though we do not know and cannot know what is going to happen we have the will to act, to "be actively participating in a world that is becoming, without knowing what it's going to be become" (de Brabandere, 2005). In many ways this ties in with how it is when we read and study a poem. There is no absolute certainty as to what the poet meant us to understand. There are no right answers.

${ }^{8}$ Luc de Brabandere is a senior advisor to BCG. He specialises in creativity, scenario building, and strategic vision techniques applied to business. 


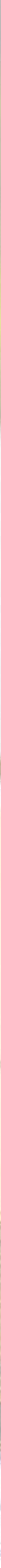

(c) Graeme Daves/123RF.COM

\section{POETRY AND ORIGINAL LEARNING}

Monika Kostera examined the contribution of poetry to research into the relationship between feelings and organising. She argues that poetry, as an approach, is well suited to expressing the ambivalence and volatility of the managerial experience. "Its strength is that it does not 'flatten out' the domains of organizing or 'translate them into rationality" (Kostera, 1997, p. 343). As a result she proposes that poetry can be used to understand more about organizational realities. Her aim in using poetry was to learn about the subversive and subjective experience of talking about management topics. She argues that poetry is particularly powerful in that it does not avoid passion and it is disruptive because it is inconclusive.

Grisoni and Kirk in their paper, Voice, Verse and Va va voom: Illuminating Management processes through Poetry (Grisoni and Kirk 2006), explored the power of using poetry as a process of critical reflection and organisational analysis in the management process. In this qualitative study poems were created from the experiences of two members of the organisation in dialogue in relation to their roles and focus on specific decision-making critical incidents within the life of the organisation. Writing in the form of poetry enabled them to find a voice, increased personal learning, and new insights in relation to roles, management processes of decision-making, and interpersonal dynamics in the organisation. Grisoni and Kirk (2006, p. 344) found that "the power of poetry lies in its ability to focus not only on events but also on behavioral and 
affective elements embedded in the episode. Poetry has been used to reveal hidden aspects of organizational life where the essence of an event or episode opens up an opportunity for greater understanding as well as the potential for change in individuals and organizations".

Louise Grisoni (2007, p. 341) argues that poetry "can be used to create a fusion between tangible, rational and explicit knowledge and tacit or implicit knowledge, providing opportunities to access new organizational knowledge and understandings and learning." Her paper is a case study of 60 middle and senior UK-based public services managers from one local authority who worked together to explore how research into their experiences might help address some problematic issues facing public services as well as developing ideas about best practice. Poetry in the form of haiku was used as a creative research method to access tacit knowledge, which, when combined with explicit knowledge and understanding, led to new insights and organisational learning. The structure for a haiku was chosen in that it channelled anxiety into the need to count syllables and ensure that the haiku that were created conformed to the 17 syllable pattern arranged in a 5, 7, 5 pattern.

In small groups of three, participants in the workshop were invited to tell each other stories about significant events from their recent organisational experiences. Listeners noted key words from these stories and together the small group developed short poems using the haiku form of poetry. Participants were encouraged to play with words rather than worry about whether the poems they created were good examples of poetry. The poems were then read back to the whole group and participants invited to capture the thoughts and feelings that emerged in hearing and understanding the new knowledge presented to them. Through this process of reflection a revised sense of the issues and priorities held in the organisation were discovered and action plans identified. It was noticed by the group that the use of poetry enabled a surfacing and discussion of emotions and emotional engagement with the organisation in a new and different - more accessible way.

\section{AND WHERE DO WE GO FROM HERE?}

In his Philosophical Investigations, Wittgenstein asserted that anyone who could not understand poetry was 'meaning blind'. He also believed that language can hide things from us; that words don't have simple and singular meanings. False perceptions of meaning can lead us to ingrained ways of thinking. He believed that one of the ways that we can be set free of this is by reading poetry. "Do not forget that a poem although it is composed in the language of information, is not used in the language game of giving information." ${ }^{\prime 9}$

Certainly more efforts are being made to bring poetry to the masses which is turn could make it more acceptable as a training device in companies and organiations. The scheme, Poems on the Underground, was launched in 1986 by London Underground to showcase a diverse range of poetry - classical, contemporary, international as well as work by new poets - with the aim of bringing poetry to the masses. Poems are displayed in 3,000 advertising spaces in train carriages across London, and are usually changed three times a year. This scheme has been highly successful resulting in the publication of several volumes of poems. In 1998 the Poetry Society in the UK launched Poetry Places - a scheme that between 1998 and 2000 placed many of the UK's leading poets in settings that would show how poetry can be part of everyday life. Writing in The Guardian when the scheme came to an end, Maev Kennedy (2000) described it as having "brought poems to the public in the most unlikely places: poems on greaseproof wrappers in Wigan chip shops, poems printed on refuse sacks in Norfolk, poems on spikes among the plants in a botanical garden, and poems on walls, bus shelters and beaches." The project generated unprecedented publicity for British poetry - when Peter Sansom became Marks and Spencer's poet-in-residence, the news went global. The Star newspaper quipped poetically:

${ }^{9}$ Wittgenstein, Ludwig. Zettel. ISBN: 9780520252448 
I wandered lonely through the crowd

At my local Mers

When all at once I saw a bard

Among the pants and vests.

Poems bridge the gap between knowing and perceiving because they use the highly differentiated, logicdriven structures of language to point to the undifferentiated arena where emotion holds sway. Poems put down their roots in the no-man's land between thinking and feeling, the borderland where logic shades into the non-logical, where a world defined and delineated by language gives way to the more diffuse territory of what psychologists sometimes call the "feeling state" (Morgan, 2010, p .55). This is the same strange land, in which twenty-first-century business executives routinely find themselves. A world in which facts and data are never enough and there is rarely a right or a wrong answer. Regularly reading, discussing, and thinking about poetry, Morgan claims, can help business professionals become more comfortable with ambiguity, and, as a result, prepare them to be creative, ethical leaders. She goes on to say that thinking contains rational and nonrational elements and making effective decisions depends on both. "Poetry brings together these rational and nonrational elements more clearly and intensely than other modes of expression" (Morgan, 2010, p. 55). She argues that reading poetry can encourage the "play between the rational and nonrational processes. This improved confluence enhances your decision-making abilities and therefore enables you to operate more fully and effectively in a complex, decision-led world" (Morgan, 2010, p. 56).

Just as "the poet isn't trying to tell you something. The poet isn't trying to tell you anything. The poet is taking you on a journey of exploration, and where you arrive in the end, and the nature of the journey, will be different for each person" (Morgan, 2010, p. 13); so this paper was a journey - an exploration - seeking to open your mind to the possibilities; to encourage you to see poetry in a different light. "If you're going to be able to think innovatively or creatively, you have to abandon the quest for swiftness of conclusion. You have to see thinking as an exploration, not just a means to an end" (Morgan, Lange and Buswick, 2005). It has explored just a few of the potential benefits that studying poetry might bring to the world of business - a world where companies need to constantly find a blue ocean to operate in by differentiating themselves from other players; developing new markets and innovative products. Has the time now come to take poetry down from the shelf, dust it off, and take a serious look at what it can do for the business world and then move on to harness that power?

This article is based on the paper "Poetry and the World of Business - an Exploration" presented by the author at the Shared Values Conference in Prague June 2 - 5, 2014. It is an extended version of the Discussion paper: "Can Poetry be of value in the world of business?" published in September 2014 in the Central European Business Review [Pritchett, Gillian. Discussion Paper: Can Poetry be of value in the world of business? CEBR September 2014. Vol 3. Number 3. pp. 54-57] who have consented to its partial reproduction here.

Gillian Pritchett, MA. CPFA. is a Business, Marketing er Social Media Strategist; Business Advisor and Adjunct professor teaching business strategy and marketing at universities in Canada, Holland, and the Czech Republic. 


\section{REFERENCES}

de Brabandere, L. (2005) The Forgotten Half of Change. BCG Perspectives. Available at: www.bcgperspectives.com/content/ articles/business_unit_strategy_change_management_the_forgotten_half_of_change/ (Accessed: 1 December 2014).

Fanning, J. (2007) 'What Business can Learn from the Poetry of Thomas Kinsella', Irish Marketing Review, 19 (1, 2), p. 46 [Online]. Available at: www.dit.ie/media/newsdocuments/2008/neweditionofirishmarketingreview/05Fanning.pdf (Accessed: 1 December 2014).

Goia, D. (1992) Can Poetry Matter?: Essays on Poetry and American Culture.[Online]. Available at : www.danagioia.net/essays/ ebusiness.htm (Accessed: 1 December 2014)

Grisoni, L. and Kirk P. (2006) 'Voice, Verse and Va va voom.: Iluminating Management processes through Poetry', Management Decision, 44(4) pp. $512-525$.

Grisoni, L. (2007) Cooking up a star: Flavouring Organisatinal Learning with Poetry, Proceedings of OLKC 2007 - "Learning Fusion", p. 341

Hughes, T. (1967) Poetry in the Making: A Handbook for Writing and Teaching. Faber and Faber, pp. 17-19.

Iser W. (1974) The Reading Process: A Phenomenological Approach: The Implied Reader. Baltimore: Johns Hopkins UP, pp. $274-294$.

Kennedy, M. (2000) 'Rhyme to go home', The Guardian, 23 March. [Online]. Available at: www.theguardian.com/ books/2000/mar/23/poetry.artsfeatures (Accessed: 1 December 2014).

Klepper, M. and Piller, I. (2000) The Language of Poetry and Advertising - an interdisciplinary teaching project, Hamburg University [Online]. Available at: http://webdoc.sub.gwdg.de/edoc/ia/eese/artic20/piller/5_2000.html (Accessed : 1 December 2014).

Kostera, M. (1997) 'Personal Performatives: Collecting Poetical Definitions of Management', Organization, 4(3), p. 343.

Lennox, Lt. Gen. William James Jr. (2006) Romance and Reality. [Online]. Available at: www.poetryfoundation.org/ poetrymagazine/article/146660 (Accessed: 1 December 2014)

Mann, J. (1999) Poetry and Business. Available at: www.poetrysociety.org.uk/content/archives/places/julesmann/posting3/ (Accessed: 1 December 2014).

Meredith, R. (2000) 'The Media Business: Advertising; Marketing departments are turning to poets to help inspire their companies' clientele', The New York Times, 21 March.

Morgan, C., Lange, K. and Buswick, T. (2005) 'Poetry in the Boardroom: Thinking Beyond the Facts: A Roundtable Discussion among Clare Morgan, Kirsten Lange, Ted Buswick, and Nancy Healy', Journal of Business Strategy, 26(1), pp. 34-40.

Morgan, C., Lange, K. and Buswick, T. (2010) What Poetry Brings to Business. Michigan: University of Michigan.

Rubin, H. (2007) 'C.E.O. Libraries Reveal Keys to Success', The New York Times, 21 July.

Sherry, J.F. Jr. and Schouten, J. W. (2002) 'A Role for Poetry in Consumer Research', Journal of Consumer Research, 29, pp. $218-234$.

Wittgenstein, L. Zettel. ISBN: 9780520252448 